\title{
PELAYANAN PENDIDIKAN BERBASIS MANAJEMEN PERUBAHAAN
}

\author{
Oleh: \\ Marto Silalahi \\ Dosen STIE Sultan Agung P. Siantar
}

\begin{abstract}
Abstraksi
Kemampuan individu, kelompok dan organisasi menyesuaikan diri dengan lingkungan internal dan eksternal akan memberikan dampak positip dalam aktivitasnya. Organisasi pendidikan dituntut profesional dan adaptif atas perubahaan yang terjadi baik dari kebijakan pada tingkat nasional, daerah maupun perkembangan dan kebutuhan organisasi. Penyesuaian diri tersebut menjadi energi kinetik dan potensial dalam meningkatkan daya saing. Kemampuan organisasi pendidikan melakukan perubahaan menjadi sumber daya dalam menghadapi persaingan baik lokal, regional maupun internasional. Managemen strategis, managemen organisasional dan managemen operasional dituntut melakukan perubahan organisasi pendidikan sesuai dengan kebutuhan organisasional dan kebutuhan stakeholder pendidikan tersebut.
\end{abstract}

Kata Kunci: Pelayanan Pendidikan dan Managemen Perubahaan.

\section{Abstraction}

The adaptation ability of individu, group and organization to internal and external environment factors have a implact to their activity. The education organization must be have a professionalism, adaption attidues to situation and condition of government policy, local government and the organization function and development. The organization adaption will be come to be kinetic energy and potensial to increase competitive resources. The ability organization of education to changeable to face the local competitive, regional or international competitive. The strategic management, organizational management and operating management must be have changing organization education in order to adapting the organization function and the stakeholders function.

\section{Keywords: Service of Education and Managemen Perubahaan}

\section{A. PENDAhUluan}

Pendidikan sudah menjadi suatu kebutuhan penting (kalau tidak bisa disebut kebutuhan primer) bagi kehidupan individu, kelompok dan organisasi. Keberhasilan suatu level pendidikan tertentu baik formal maupun non formal, menjadi barometer bagi pencari pekerjaan. Untuk mendaftar suatu lowongan pekerja tertentu misalnya pada dunia perbankan, maka perbankan tersebut membuat berbagai persyaratan (misalnya sarjana ekonomi, sarjana hukum) dan tambahan persyaratan lain yaitu pelamar harus menguasi akuntansi yang berbasis komputer, menguasi bahasa inggris, bahasa mandarin, dan sebagainya. Ekspektasi organisasi publik/privat yang membutuhkan tenaga kerja tersebut disesuaikan dengan percepatan pertumbuhan dari organisasi. Kompetensi dan daya saing yang dimiliki individu membuat pekerjaan organisasi menjadi lebih mudah dan lebih berhasil dibanding dengan tenaga kerja yang ada sebelumnya.

Pertambahan penduduk (belum tentu disertai dengan peningkatan kualitas pendidikan) menuntut berbagai kebutuhan yang harus dipenuhi individu, kelompok dan organisasi. Pertambahan penduduk (bonus demograsi pada tahun 2050) mensyaratkan perubahaan strategis yang harus dilakukan stakeholder pendidikan baik pemerintah, masyarakat /civil society (pemerhati pendidikan kelompok/organisasi masyarakat penyelenggara pendidikan) dan dunia kooporasi (termasuk yayasan pendidikan, dan sebagainya).

Pertumbuhan penduduk membutuhkan pertumbuhan organisasi pendidikan yang profesional, kompeten dan akuntabel. Pertumbuhan organisasi pendidikan tersebut akan mengikuti proses dan seleksi alam bahwa organisasi pendidikan yang mampu menyesuaikan diri dengan layanan pendidikan yang dibutuhkan individu, kelompok dan organisasi, menjadi pemenang atas persaingan tersebut.

Organisasi pendidikan sebagai wadah/ sarana menciptakan manusia yang berpikir sistematis dan bertindak komprehensif, diharapkan melakukan serangkaian perubahaan yang dapat mewujudnyatakannya. Melalui organisasi yang profesional, kompeten dan akuntabel, penciptaan manusia/individu yang berpikir sistematis dan bertindak komprehensif tersebut, menjadi sumber daya manusia yang dapat digunakan organisasi privat (dunia korporasi) dan organisasi publik (pemerintahan). Sinergitas organisasi pendidikan dengan organisasi yang menyedikan membutukan tenaga kerja adalah barometer keberhasilan pelayanan pendidikan yang diselenggarakan organisasi pendidikan baik yang dilaksanakan pemerintah maupun yang dilaksakan masyarakat madani (organisasi pendidikan yang dilaksanakan yayasan pendidikan miliki perorangan atau milik kelompok). 
Stakeholder mencerdaskan kehidupan bangsa melalui dimensi pendidikan menjadi tugas mulia semua komponen bangsa indonesia sebagaimana diamanatkan pembukaan undang-undang dasar atau konstitusi. Dalam rangka melaksanakan amanat konstitusi tersebut, berbagai lembaga pendidikan yang dikelola organisasi kemasyarakatan melaksanakan berbagai tingkatan pendidikan. Lembaga pendidikan yang dikelola organisasi masyarakat tersebut patut dan wajar diberikan penghargaan pemerintahan. Apresiasi pemerintahan terhadap keberdayaan organisasi pendidikan yang dikelola organisasi kemasyarakatan, terlihat dari berbagai bantuan yang diberikan pemerintah, misalnya bantuan bagi mahasiswa yang berprestasi, bantuan asistensi, bantuan mobilier dan sebagainya.

Sehubungan betapa pentingnya keberadaan management perubahaan pada organisasi pendidikan, Lewin (dalam Robbins, 2006), mengatakan bahwa ada tiga langkah untuk mengelola perubahaan organisasi, yaitu 1) Melelehkan (Unfreezing), 2) Gerakan kearah yang baru dan 3) Membekukan (Refreezing). Dalam kehidupan organisasi pendidikan keberadaan daya berubah (the ability to face the change) merupakan suatu kebutuhan organisasi bila tidak organisasi pendidikan tersebut akan mendekati kematian atau bubar atau dimerger oleh organisasi lainnya. (the death of organization). Perkembangan organisasi pendidikan menyesuaikan diri dengan lingkungan internal atau lingkungan eksternal menjadi indikator keberhasilan daya berubah organisasi itu sendiri.

\section{B. PEMBAHASAN}

\section{Melelehkan (Unfreezing)}

Keberhasilan organisasi pendidikan mencapai visi dan misinya membutuhkan dukungan dari semua stakeholder pendidikan. Tidak dapat dipungkiri bahwa organisasi pendidikan memiliki dimensi idealisme dan dimensi komersial. Pada dimensi idealisme bahwa organisasi pendidikan itu menjalankan visi dan misinya untuk mencerdaskan kehidupan bangsa sebagaimana amanat konstitusi negara. Mencerdaskan kehidupan masyarakat dan bangsa melalui faktor pendidikan memberikan kontribusi yang besar bagi percepatan terwujudnya individu yang berlatar belakang berpikir sismatis dan bertindak komprehensif. Pada akhirnya masyarakat atau warga bangsa, memberikan kontribusinya dalam percepatan pembangunan dan kemakmuran yang berkeadilan dan amanah melalui fungsi dan peranannya masing-masing. Pada dimensi komersial, organisasi pendidikan memiliki tugas dan fungsi sebagaimana diamanatkan peraturan yang dibuatkan yayasan pendidikan itu sendiri.

Layaknya sebagai organisasi modern, organisasi pendidikan juga membutuhkan keberadaan sumber daya manusia, sumber dana, sumber daya material, sumber daya minute dan sumber daya metode. Kebutuhan berbagai sumber daya itu menjadi fondasi keberhasilan pencapaian visi dan misi organisasi pendidikan. Keberadaan sumber dana/modal misalnya, dapat diibaratkan seperti keberadaan darah bagi manusia, atau keberadaan bensin bagi kenderaan bermotor.

Prinsip ekonomi 'Dengan menggunakan modal sekecil-kecilnya, mendapat untung sebesarbesarnya' masih relevan digunakan organisasi pada umumnya termasuk organisasi pendidikan. Kehidupan sumber daya manusia yang bekerja dalam organisasi pendidikan merupakan faktor yang sangat penting, karena keberadaan sumber daya lainnya akan tidak maksimal fungsinya bila tidak adanya manusia. Kebutuhan manusia (lima kebutuhan manusia sebagaimana disampaikan Abraham Maslow) menjadi alasan logis dan ilmiah bahwa manusia membutuhkan berbagai kebutuhan (pangan, sandang dan perumahan misalnya).

Keberdayaan sumber daya organisasi pendidikan menjadi faktor utama keberhasilan organisasi pendidikan dalam mencapai visi dan misinya. Partisipai aktif stakeholders organisasi pendidikan baik perencanaan, pelaksanaan maupun pengawasan setiap program dan kegiatan yang sedang dilaksanakan ataupun yang akan dilaksakan. Seberapa besar keberhasilan organisasi sangat tergantung kepada seberapa besar kontribusi stakeholder organisasi itu sendiri. Namun demikian, silogisme negatif, juga akan berlaku dalam kegagalan organisasi pendidikan dalam mencapai visi dan misi. Keberhasilan dan atau kegagalan organisasi pendidikan sangat tergantung kepada kontribusi komponen organisasi dalam pengujudnyataan visi dan misi organisasi pendidikan itu sendiri. Kinerja anggota/individu, kelompok dan atau kinerja seluruh komponen organisasi pendidikan merupakan totalitas kontribusi kinerja optimal bagi keberhasilan pencapaian visi dan misi organisasi pendidikan.

Ada beberapa faktor yang menghalangi terjadinya perubahaan pada umumnya, (Soekanto, 2005), yaitu (1) Kurangnya hubungannya dengan masyarakat lain, (2) Perkembangan ilmu pengetahuan yang terlambat ; (3) Sikap masyarakat sangat tradisional ; (4) Adanya kepentingan yang telah tertanam dengan kuat atau vested interests ; (5) Rasa takut akan terjadinya kegoyahan pada integrasi kebudayaan ; (6) Prasangka terhadap hal-hal baru atau asing atau sikap yang tertutup ; (7) Hambatan yang ideologis ; (8) Adat dan kebiasaan ; (9) Niat bahwa hidup ini pada hakekatnya buruk dan tidak mungkin diperbaiki.

Pelayanan pendidikan yang dilakukan organisasi pendidikan misalnya sekolah menengah kejuruan akan lebih bermanfaat bila pelayanan pendidikan itu dapat sinergis dengan kehidupan masyarakat sekitarnya. Terasa kurang manfaatnya bila pelayanan pendidikan yang dilakukan sekolah menengah kejuruan penerbangan di daerah pertanian. Terasa kurang manfaatnya bila pelayanan pendidikan yang dilakukan perguruan tinggi (program studi kelautan misalnya ) bila daerah itu 
adalah dominan daerah pertanian. Terasa besar manfaatnya bagi masyarakat bila perguruan tinggi (program studi peternakan misalnya) dapat membina dan mengajari masyarakat bagaimana cara/tehnik berternak sapi yang baik dan benar. (misalnya masyarakat di daerah bandung - lembang di Jawa Barat).

Sinergitas kinerja organisasi pendidikkan dengan aktivitas organisasi publik atau oganisasi privat akan memberikan jawaban sementara atau jawaban permanen atas berbagai permasalahan yang dihadapi. Perguruan tinggi sebagai organisasi pendidikan diharapkan dapat mengaktualisasi hasil penelitiannya bagi kehidupan masyarakat. Kemajuan ilmu pengetahuan melalui kehadiran alat elektronik dan tehnologi (misalnya laptop, satelit, dan sebagainya) akan mempermudah dan memperlancar aktivitas kehidupan masyarakat atau pemerintahan.

Pelayanan pendidikan yang dilakukan perguruan tinggi melalui penelitian ketersediaan energi alternatif (misalnya buah pohon jarak dapat dijadikan energi alternatif) dapat membantu pemerintah dalam kebijakan energi/perminyakan nasional. Terasa bermanfaat bagi masyarakat dan pemerintah bila pelayanan pendidikan perguruan tinggi berhasil memproduksi mobil hemat energi. Terasa bermanfaat bagi masyarakat dan pemerintah, bila pelayanan pendidikan perguruan tinggi berhasil memproduksi alat peteksi bencana alam,gunung meletus dan tsunami.

Mencerdaskan masyarakat melalui olah pikir dan olah rasa akan memproduksi aktivitas masyarakat yang bermanfaat. Pelayanan organisasi pendidikan diharapkan dapat meningkatkan perbaikan kehidupan anggota masyarakat (mahasiswa merupakan anak dari anggota masyarakat). Pelayanan organisasi pendidikan melalui transfer ilmu pengetahuan dan transfer perilaku dan tindakan akan berkontribusi bagi perbaikan sikap dan tindakan anggota masyarakat dan secara bertahap akhirnya akan memperbaiki kehidupan masyarakat.

Transfer ilmu pengetahuan dan transfer sikap dan tindakan merupakan bagian integral dari kehadiran kebudayaan dalam kehidupan masyarakat. Menurut Kluckhohn (Soekanto, 2005), mengatakan bahwa terdapat tujuh unsur kebudayaan, yaitu (1) Peralatan dan perlengkapan hidup manusia, (2) mata pencaharian dan sistem ekonomi, (3) Sistem kemasyarakatan, (4) Bahasa, (5) Kesenian, (6) Sistem pengetahuan dan (7) Sistem religi.

Pendidikan melalui sistem pengetahuan merupakan kebutuhan manusia, kelompok atau masyarakat. Produktivitas organisasi pendidikan (melalui manusia yang berkinerja optimal dan manusia yang bersikap dan bertindak amanah) akan mempermudah dan memperlancar aktivitas manusia dan masyarakat. Kehadiran tehnologi sebagai aplikasi ilmu pengetahuan, merupakan produksi dari pelayanan organisasi pendidikan. Organisasi pendidikan diharapkan mendesain program dan kegiatan yang bersinergi dengan kehidupan masyarakat, kehidupan organisasi publik dan atau organisasi privat.

Setiadi,dkk (2012:165) ; Mengatakan bahwa teknologi dianggap sebagai sebagai penerapan ilmu pengetahuan, dalam pengertian bahwa penerapan itu menuju pada perbuatan atau perbuatan atau perujudan sesuatu. Saing memberi penekanan kepada sumbangan pemikiran manusia, dalam menguasai ilmu pengetahuan yang terdapat dalam alam semesta. Sain sangat penting untuk perkembangan dan kemajuan kemanusiaan. Sebagai wadah penciptaan manusia yang kreatif, inovatif, dan profesionalism, kehadiran organisasi pendidikan yang adaptif menjadi suatu keharusan dan kebutuhan bagi masyarakat dan pemerintah. Pelayanan organisasi pendidikan akan memproduksi manusia yang memiliki ilmu pengetahuan dan pada akhirnya memberikan manfaat bagi masyarakat dan kemanusiaan.

\section{Gerakan Kearah Keadaan Yang Baru}

Partisipasi stakeholders pendidikan atas berbagai program dan kegiatan organisasi pendidikan merupakan modal utama bagi keberhasilan pelayanan pendidikan. Ketersediaan sumber daya manusia yang profesional, kompeten dan akuntabel, sumber dana dan sumber daya lainnya menjadi jalan pendekat bagi kemudahan dan kelancaran pelayanan pendidikan yang optimal (the excellence of education services). Kesatuan arah perubahan sebagaimana yang diharapkan stakholder pendidikan akan memberikan kesatuan tindakan pencapaian visi dan misi organisasi pendidikan. Stakeholder pendidikan merupakan agen perubahaan atas pelayanan pendidikan yang optimal. Kesatuan arah dan tindakan akan memperlancar perubahan pelayanan pendidikan.

Memperhatikan organisasi pendidikan, kehadiran perubahan tidak dapat dihindari atau ditiadakan. Dari faktor organisasi, Lewin (dalam Robbins, 2006), perubahaan yang terjadi bersumber dari : (1) Kelembagaan struktural ; (2) Ancamana terhadap alokasi sumber daya ; (3) Ancaman terhadap hubungan dengan kekuasaan ; (4) Ancaman terhadap keahlian ; (5) Kelembaban kelompok ; (6) Faktor perubahaan terbatas. Keterbatasan organisasi pendidikan terlihat dari berbagai kelemahan atau kekurangan yang dimiliki organisasi pendidikan. Keterbatasan dosen bagi perguruan tinggi misalnya, menjadi potensi kegagalan melayani peserta didik, masyarakat dan stakeholder pendidikan lainnya. Ketidakhamonisan dengan stakeholders pendidikan khususnya pemerintah, akan membuahkan tidak optimalnya kinerja pelayanan organisasi pendidikan.

Tidak dapat dibayangkan apa yang terjadi bila sekolah menengah atas misalnya, tidak mengikuti atau mempedomani kurikulum 2013 sebagaimana telah ditetapkan pemerintah. Profesionalitas, kompetensi dan akuntabilitas tenaga pendidik (guru,dosen) memberikan kontribusi yang besar atas perubahan pelayanan organisasi pendidikan. Tidak dapat dibayangkan proses belajar 
mengajar bila ada suatu perguruan tinggi memiliki keterbatasan kuantitas dan kualitas tenaga pendidik. Mengelola potensi kegagalan perubahan pelayanan pendidikan, menjadi tugas berat dari semua komponen organisasi pendidikan. Keberdayaan sumber daya organisasi diharapkan menjadi jalan keluar dari potensi kegagalan perubahan yang telah direncanakan organisasi pendidikan.

Pengelolaan sumber daya organisasi pendidikan secara optimal akan memberikan kontribusi bagi perubahaan yang terencana sebagaimana tersusun dalam visi dan misi organisasi pendidikan. Terkait dengan riset tindakan yang dilakukan atas perubahaan yang terencana, Lewin (dalam Robbins, 2006), mengatakan bahwa riset tindakan memiliki lima langkah, yaitu (1) Diagnosis ; (2) Analisis ; (3) Umpan balik ; dan (4) Tindakan dan (5) Evaluasi. Managemen strategis, managemen organisasional dan managemen operasional dituntut memiliki kemampuan mendiagnosis faktor yang potensial yang mendukung perubahan yang direncanakan atau faktor yang potensial yang menggagalkan perubahaan yang telah direncanakan sebelumnya. Dengan mengetahui faktor tersebut, keberhasilan pencapaian visi dan misi organisasi pendidikan sudah semakin dekat.

Melakukan analisis faktor pengganggu atau faktor pendukung/pensukes perubahaan yang sudah direncanakan akan mendukung efektivitas dan efesiensi penggunaan sumber daya organisasi pendidikan. Keterbukaan informasi dan komunikasi sumber daya manusia akan menghasilkan suatu perencanaan tindakan yang komprehensif. Action plan organisasi pendidikan harus diwujudnyatakan dalam real action dari semua pemangku pendidikan yang dalam organisasi pendidikan.

Perbaikan hari demi hari atas perubahaan yang terjadi (baik sesuai dengan rencana sebelumnya ataupun tidak sesuai dengan rencana) menjadi sarana utama meningkatkan daya saing organisasi pendidikan. Tidak dapat dibayangkan apa yang terjadi dalam organisasi pendidikan bila program dan kegiatan yang telah direncanakan digagalkan akibat kealpaan atau kesalahan pemangku pendidikan. Tegaknya aturan misalnya statuta perguruan tinggi, menjadi landasan legal bagi pendisplinan semua pemangku kepentingan agar memberikan pelayanan pendidikan yang optimal sesuai dengan tugas dan fungsinya.

\section{Membekukan (Refreezing)}

Pelayanan pendidikan yang dilakukan organisasi pendidikan harus mempertimbangkan kekuatan pendorong dan kekuatan penekan. Keberadaan sumber daya lingkungan internal dan lingkungan eksternal terlihat dari seberapa dampak positip atau dampak negatif atas keberhasilan pencapaian visi dan misi organisasi pendidikan. Tidak dapat dibayangkan kinerja pelayanan, bila suatu sekolah menengah atas tidak memperhatikan faktor kekuatan ( kinerja optimal guru,tenaga administrasi) dan faktor kelemahan (keterbatasan sarana dan prasarana seperti masih memakai kapur tulis, tidak memiliki komputer, dan sebagainya).

Dalam organisasi baik publik atau organisasi privat termasuk organisasi pendidikan sudah pasti memiliki kekuatan dan kelemahan. Bagaimana mengelola kelemahan menjadi kekuatan dan meningkatkan kontribusi kekuatan menjadi pertanyaan yang harus terus menerus dipikirkan dan dicarikan jalan keluarnya oleh managemen strategis, managemen organisasional dan managemen operasional yang ada dalam organisasi pendidikan.

Pengembangan organisasi (Organizational Development) menjadi salah satu faktor yang perlu dipertimbangkan agar pelayanan pendidikan dapat mencapai visi dan misi secara optimal. Mengelola kekuatan dan kelemahan sumber daya organisasi pendidikan membutuhakan perencanaan, pelaksanaan dan mengawasan yang sistematis dan tersusun dalam grand desain kebijakan organisasi pendidikan. Mendesain perubahan pelayanan pendidikan dilakukan dengan merubah tugas dan fungsi dari masing-masing sumber daya manusia yang menduduki struktur organisasi pendidikan itu sendiri. Penempatan tenaga pendidikan (baik guru maupun dosen) diarahkan sesuai dengan kualifikasi dan kompetensi yang dimiliki. Penguatan faktor penguasaan materi pembelajaran misalnya, akan memberikan dampak dalam transfer pengetahuan. Tidak dapat dibayangkan kualitas peserta didik bila tenaga pendidikan kurang memahami materi pembelajaran.

Pengembangan organisasi pendidikan melalui penguatan kualitas tenaga pendidikan menjadi faktor utama bagi keberhasilan pelayanan pendidikan yang prima. Disamping itu, penguatan tenaga pendidikan yang menempati struktur organisasi pendidikan baik yang bersifat administratif maupun yang bersifat edukatif menjadi sumber daya tambahan bagi perbaikan pelayanan pendidikan. Ada beberapa alasan mengapa organisasi melakukan perubahan (Terry,1996), yaitu : (1) Hasil yang timbul karena pengorganisasian menyebabkan timbulnya perubahaan ; (2) Perubahaan personil ; (3) Terjadinya perubahan pada produk, jasa (service) dan metode ; (4) Senantiasa diusahakan perbaikan.

Organisasi pendidikan membutuhkan pengembangan organisasi dalam arti perbaikan dalam visi dan misi yang dijalankan. Perbaikan terus menerus (daya to day renewable function) akan memberikan perbaikan dalam pelayanan pendidikan itu sendiri. Perbaikan yang dilakukan organisasi pendidikan mengikuti perkembangan kebijakan yang dikeluarkan organisasi pemerintahan. Misalnya, penerapan kurikulum 2013 merupakan kebijakan pemerintah yang harus dipedomani sekolah negeri atau sekolah swasta. Penambahan atau pengurangan personil / tenaga kependidikan dimaksudkan untuk perbaikan pelayanan pendidikan itu sendiri. Tour of duty (penugasan di struktur organisasi yang lain ) atau tour of area (penugasan di daerah penempatan yang lain) adalah contoh kebijakan organisasi agar 
sumber daya kependidikan memiliki kualitas yang kompeten dan akuntabel. Perubahan visi dan misi organisasi pendidikan khususnya metode pembelajaran akan memberikan dampak bagi pelayanan pendidikan yang dijalankan. Pengembangan organisasi pendidikan dilakukan untuk perbaikan kualitas pelayanan pendidikan itu sendiri.

\section{KESIMPULAN DAN SARAN}

Peningkatan kualitas manusia menjadi tugas dari semua komponen bangsa dan negara Indonesia. Penguatan sumbangan pemangku kepentingan pendidikan atas kualitas manusia menjadi faktor utama dalam perbaikan pelayanan pendidikan. Organisasi pendidikan baik yang berada dalam lingkup kerja organisasi pemerintah maupun yang berada dalam lingkup organisasi privat (yayasan, perorangan) memiliki tugas mulia bagi peningkatan atau perbaikan kualitas manusia Indonesia. Kebijakan pemerintah menjadi grand desain perbaikan kualitas pelayanan pendidikan.

Pengembangan organisasi pendidikan melalui perbaikan semua komponen organisasi pendidikan menjadi jawaban organisatoris disamping kebijakan organisasi pendidikan lainnya. Keberadaan lingkungan internal dan lingkungan eksternal patut diperhitungkan organisasi pendidikan. Kontribusi perbaikan yang diberikan lingkungan internal dan lingkungan eksternal menjadi modal utama bagi perbaikan pelayanan pendidikan. Keberhasilan dan atau kegagalan organisasi pendidikan sangat tergantung kepada kontribusi komponen organisasi dalam pengujudnyataan tujuan atau sasaran dari organisasi pendidikan itu sendiri. Kinerja anggota/individu, kelompok dan atau kinerja seluruh komponen organisasi pendidikan merupakan totalitas kontribusi kinerja optimal bagi keberhasilan pencapaian visi dan misi organisasi pendidikan.

Stakeholder pendidikan merupakan agen perubahaan atas pelayanan pendidikan yang optimal. Kesatuan arah dan tindakan akan memperlancar perubahan pelayanan pendidikan. Pengembangan organisasi pendidikan melalui penguatan kualitas tenaga pendidikan menjadi faktor utama bagi keberhasilan pelayanan pendidikan yang prima. Disamping itu, penguatan tenaga pendidikan yang menempati struktur organisasi pendidikan baik yang bersifat administratif maupun yang bersifat edukatif menjadi sumber daya tambahan bagi perbaikan pelayanan pendidikan

\section{DAFTAR PUSTAKA}

Jones. C.O.1996, Pengantar Kebijakan Publik. Jakarta : Raja Grafindo Persada.

Kumorotomo. Wahyudi. 1999. Etika Administrasi Negara. Jakarta PT. Rajafindo Persada.

Rasyid. M.Ryass. 1996. Makna Pemerintahan. Jakarta : PT. Yarsif Watampone.

Robbins. Stephen P. 2006. Perilaku Organisasi. Terjemahan Benyamin Molan. Jakarta : Indeks.

Soerjono, Soekanto. 2005. Sosiologi Suatu Pengantar. Jakarta : RajaGrafindo Persada.

Supriatna. Tjahja. 1997. Birokrasi, Pemberdayaan dan Pengentasan kemiskinan. Bandung : Humaniora Press.

Thoha, Miftah. 2003. Birokrasi dan Politik di Indonesia, Jakarta : PT. Raja Grafindo Persada.

Terry, George.1986. Asas - asas Managemen. Bandung : Alumni.

Setiadi,dkk. 2012. Ilmu sosial budaya dasar. Jakarta : Kencana Prenada Media Group. 